\title{
The effect of dietary fibre sources on aflatoxicosis in the weanling
}

\section{male rat}

\author{
BY D. L. FRAPE \\ The Priory, Church Yard, Mildenhall, Suffolk IP28 $7 E E$ \\ AND B. J. WAYMAN AND MARY G. TUCK \\ Dalgety Spillers Ltd., Research \& Technology Centre, Station Road, Cambridge CBI $2 J N$
}

(Received 11 May 1980 - Accepted 9 April 1981)

\begin{abstract}
1. Two experiments with male weanling rats were conducted in which they received individually and restrictedly either a basal semi-purified diet containing starch as the principal carbohydrate or the same diet to which mixed aflatoxins were added in quantites providing from 0.13 to $0.4 \mathrm{mg}$ aflatoxin $\mathrm{B}_{1} / \mathrm{kg}$ diet. Various natural ingredients, or semi-purified sources of dietary fibre were-substituted for a portion of the starch in the basal diet containing aflatoxin. The diets were fed for 13-14 weeks after which the rats were given ad lib. a commercial rodent diet until they were killed at 109 weeks of age.

2. Two further experiments were conducted in which twenty-four rats in each experiment received the basal diet plus aflatoxin, or diets in which a portion of the starch was replaced by gum arabic or by wheat offal. After 13 or more weeks the absorption, retention and excretion of ${ }^{14} \mathrm{C}$-labelled aflatoxin $\mathrm{B}_{1}$ was measured in each rat.

3. The addition of gum aratic or wheat bran to the diet decreased the effects of the toxin in the first two experiments, but as measured by several characteristics, only wheat bran provided an effect which persisted during the period when neither it nor the toxin was given. The effects included an apparent reduction in tumour incidence. The change in the content of starch in the basal diet, occurring as a consequence of adding the test ingredients is also considered to be an associated cause of the effects observed.

4. In comparison to starch, wheat offal increased the total ${ }^{14} \mathrm{C}$ in the faeces and the proportion of the total found during the first $48 \mathrm{~h}$ after dosing. Rats receiving starch excreted more ${ }^{11} \mathrm{C}$ in their urine and retained more ${ }^{14} \mathrm{C}$ in their livers. The differences between gum arabic and starch were not significant as measured by ${ }^{14} \mathrm{C}$ excretion and retention. Liver size as a proportion of carcass weight was less in rats receiving wheat offal or gum arabic, and rats receiving wheat offal had a lower incidence of fat-loaded hepatocytes.

5. The interaction of dietary toxins, or drugs, with the ingredient composition of diet may affect animal response even when the diets ar's adequate and similar in nutrient composition. This may be of significance both in drug-safety studies and in animal production.
\end{abstract}

Dissimilarities in the hepatic response of rats to aflatoxin have been noted and attributed to genetic differences (Alf.n-Slater et al. 1975) and to nutrient supply (Rogers \& Newberne, 1971). In our previous investigations (Frape et al. 1981 a,b) a large disparity was found between experiments in the response of the weanling rat, particularly in liver size (Fig. 1), presence of hyperplastic nodules and fibrosis. Differences between experiments in terms of the ingredient composition of basal diets appeared to account for at least a part of the disparity. Wogan et al. (1974) speculated that purified diets may increase the sensitivity of the Fischer rat to hepatocellular abnormalities caused by aflatoxin and therefore the purpose of these experiments was to investigate the possibility that the addition of wheat offal to semi-synthetic diets may have contributed to the difference in response between our previous experiments. The susceptibility of the male rat to hepatotoxicity and carcinogenicity was measured when a nutritionally-adequate semi-synthetic diet was supplemented with wheat offal or other sources of structural carbohydrate in partial substitution of maize starch.

The adsorption of toxins by dietary fibre in the intestines has been suggested as a mechanism for reducing absorption but supporting scientific evidence is lacking. Wheat bran may indirectly influence the absorption of fat-soluble toxins by its effect on the secretion 


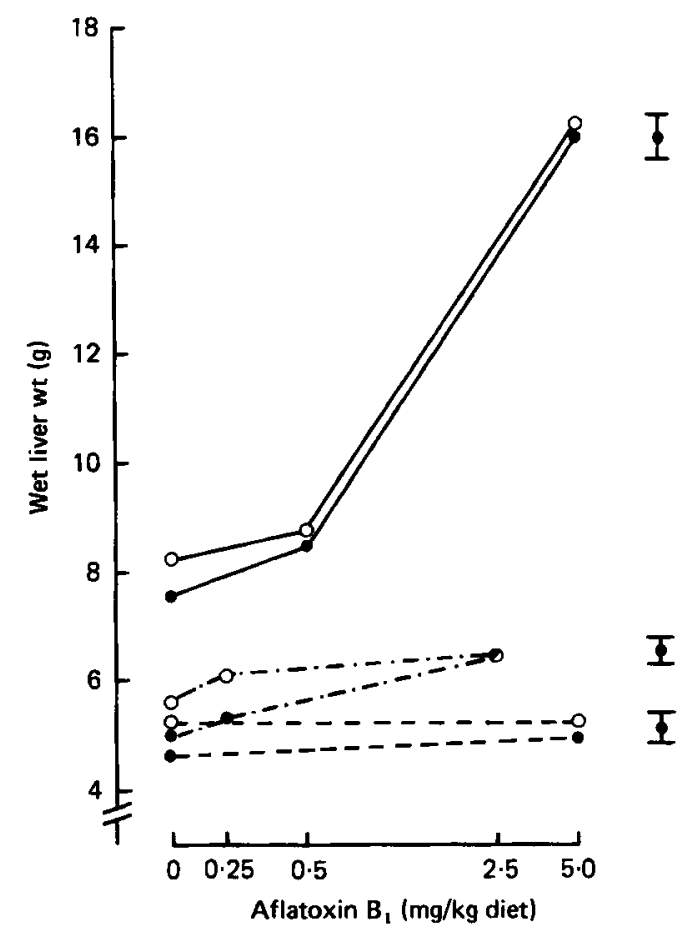

Fig. 1. The relationship between wet liver weight and aflatoxin dose in three experiments. In two of these the basal diets contained wheat offal $(---,-\cdot-)$ and in the third a semi-purified basal diet was used $(\longrightarrow)$. In each experiment the diets contained low $(O)$ and high $(\Theta)$ concentrations of essential nutrients. Standard errors, represented by vertical bars are for all means within the experiment.

and absorption of bile (Riottot et al. 1975; Wicks et al. 1978) and by its effect on faecal losses of bile acids and cholesterol (Owen et al. 1975; Yacowitz et al. 1976; Ranhotra et al. 1977). Therefore two experiments were conducted to measure the effect of two partial substitutes for starch on the intestinal absorption, excretion and liver retention of aflatoxin $B_{1}$ and its metabolites in male rats by the use of ${ }^{14} \mathrm{C}$-labelled aflatoxin $B_{1}$. The substitutes were wheat offal and gum arabic, the structural carbohydrates of which are rich in hemi-celluloses.

\section{EXPERIMENTAL \\ Expt 1}

Eighty weanling male $F_{1}$ cross-bred (Albino $\times$ Hooded, Spillers inbred strains, cross-bred) rats were used, caged singly on solid floors. They were allocated to the five diets at random from replicate groups of uniform initial weight. The basal diet used in Expts 1 and 2 contained (g/kg): egg albumen (heated for $10 \mathrm{~min}$ at $80^{\circ}$ to destroy avidin) 50 , crude casein 170 , sucrose 250 , maize starch 363 , maize oil 100 , calcium hydrogen orthophosphate 30 , sodium chloride 4 , dipotassium hydrogen phosphate 13 , sodium bicarbonate $12 \cdot 5$, hydrated magnesiun sulphate $\left(\mathrm{Mg} \mathrm{SO}_{4} \cdot 7 \mathrm{H}_{2} \mathrm{O}\right) 6$, trace mineral and vitamin supplement 1.5. The trace element and vitamin supplement provided $(\mathrm{mg} / \mathrm{kg}$ diet): manganese 50 , iron 100, copper 14 , zinc 49 , iodine $0 \cdot 2$, selenium $0 \cdot 1$, cobalt $0 \cdot 1$, DL $\alpha$-tocopheryl acetate 60 , menaphthone 5 , retinyl palmitate 4 , cholecalciferol $0 \cdot 04$, thiamin hydrochloride 2 , pyridoxine hydrochloride 5 , nicotinic acid 10 , calcium pantothenate 8 , ascorbic acid 8 , riboflavin 2.5 , choline chloride 2000 , biotin 0.08 , folic acid 5 , cyanocobalamin 0.025 . 
The five dietary treatments consisted of the basal (diet A) and four diets (B, C, D and E) to which $0.17 \mathrm{mg}$ aflatoxin $\mathrm{B}_{1} / \mathrm{kg}$ in a mixed aflatoxin extract from Aspergillus flavus (Whatman Biochemicals) were added. In two of these four diets either $150 \mathrm{~g}$ wheat offal $/ \mathrm{kg}$ (diet C) (Frape et al. 1979), or $150 \mathrm{~g}$ lucerne meal $/ \mathrm{kg}$ (diet E) replaced $150 \mathrm{~g}$ maize starch and cellulose (Solkafloc; Brown Corp. New York)/ $\mathrm{kg}$, maintaining a constant crude fibre level, and in a third, $100 \mathrm{mg}$ caffeine $/ \mathrm{kg}$ (diet D) were added (Table 1). These diets were given restrictedly in one rneal/d for $93 \mathrm{~d}$ after which they were replaced by a commercial rodent diet (Rodent Breeding Diet-Expanded; Spratts Patent Ltd, Barking, Essex), given ad lib. Fifteen rats were killed with nitrogen gas, in three replicate groups of five, between days 93 and 95 following a $20 \mathrm{~h}$ fast. The remaining sixty-five rats were killed after 738-746 d on experiment. At death the main organs were weighed and retained for histological investigations.

Serum albumin was determined by the method of Ness $e t$ al. (1965). Serum globulins were separated in sodium barbitone buffer, $\mathrm{pH} 9 \cdot 25$, by electrophoresis on cellulose acetate strips, eluted after staining with Acid Red 112/CT and the absorbance of the eluate determined at $512 \mathrm{~nm}$.

\section{Expt 2}

Cross-bred male weanling rats were again used in this experiment and managed similarly to those in the previous experiment. Ten rats in each of eight treatments were individually caged. The basal diet (A) was that used in Expt 1. Mixed aflatoxins (Whatman Biochemicals Ltd), providing approximately $0.13 \mathrm{mg}$ aflatoxin $B_{1} / \mathrm{kg}$, were added to the basal to form diet $B$. The same amount of aflatoxin was included in the next three diets together with either $60 \mathrm{~g}$ Solka floc $/ \mathrm{kg}$, (diet C), $60 \mathrm{~g}$ citrus pectin $/ \mathrm{kg}$ (diet D), $60 \mathrm{~g}$ gum arabic $/ \mathrm{kg}$ (diet $\mathrm{E}$ ), or $300 \mathrm{~g}$ wheat offal $/ \mathrm{kg}$ (diet F), replacing the same amounts of maize starch. Diet $\mathrm{G}$ was of the same composition as the basal but contained mixed aflatoxins providing approximately $0.4 \mathrm{mg}$ aflatoxin $B_{1} / \mathrm{kg}$. Diet $\mathrm{H}$ contained this amount of aflatoxin together with $120 \mathrm{~g}$ gum arabic/kg partially replacing maize starch.

The rats received these diets for $101 \mathrm{~d}$, but those which had not consumed their allowance were retained on their diets for a further $14 \mathrm{~d}$ in an endeavour to equate the dose of aflatoxin with that of their respective controls. This objective was not achieved satisfactorily owing to the apparent toxicity, and the food intakes are given in Table 2. After this period the rats were given Powdered Rodent Diet-Expanded (Spratts Patent Ltd) ad lib. and killed for examination $742 \mathrm{~d}$ from the commencement of the experiment.

Organ weights were adjusted by covariance on carcass weight in each experiment only where the adjustment significantly reduced residual variation or significantly affected mean responses. Histological examination and scoring of liver sections, stained with $\mathbf{H}$ and $\mathrm{E}$, was carried out on all rats by one of us (DLF) without previous knowledge of the treatments from which each was derived.

\section{Expt 3}

Twenty-four weanling male $F_{1}$ cross-bred rats (hooded $\times$ albino, cross-bred, as used in Expt 2) were allocated to two dietary treatments. Diet $J$ had the same basal composition as diet $A$ in Expt 2 and diet $K$ was the same as diet $H$, in as much as $120 \mathrm{~g}$ maize starch $/ \mathrm{kg}$ in diet $\mathrm{J}$ were replaced by $121 \mathrm{~g}$ gum arabic. Both diets contained mixed aflatoxins providing aflatoxin $B_{1}$ at a concentration of $0.35 \mathrm{mg} / \mathrm{kg}$ in a similar mixture of Aspergillus flavus metabolites to that used in Expt 2. The dietary aflatoxin concentration was increased in stages after $49 \mathrm{~d}$ so that a concentration of $2.5 \mathrm{mg}$ aflatoxin $\mathrm{B}_{1} / \mathrm{kg}$ diet was achieved by the 74 th day but the food consumption was restricted to $8 \mathrm{~g} / \mathrm{rat}$ daily. One day's food was omitted $82 \mathrm{~d}$ from the initiation of the experiment and on the following day $0.8 \mu \mathrm{Ci}$ ${ }^{14} \mathrm{C}$-labelled aflatoxin $B_{1}$ were added to a feed of $6 \mathrm{~g} / \mathrm{rat}$, which was consumed within $0.5 \mathrm{~h}$ of access. On the followirig day and for the remainder of the study $9 \mathrm{~g} / \mathrm{d}$ were given. 
Tail cups were fitted (Frape et al. 1970), $24 \mathrm{~h}$ before administering the tracer, for the collection of faeces and were removed $72 \mathrm{~h}$ after giving the tracer. Faecal collection continued for a further $4 \mathrm{~d}$ during which the pellets were caught on a stainless steel grid under the cages, so that periods of $0-72 \mathrm{~h}$ and $72-168 \mathrm{~h}$ were formed. All faeces were held at $-20^{\circ}$ until they were freeze-dried. Urine was collected in $1.0 \mathrm{M}$-acetic acid from $45 \mathrm{~min}$ after administering the tracer until $7 \mathrm{~d}$ later, but that excreted during the first $48 \mathrm{~h}$ was separated from that excreted during the following $120 \mathrm{~h}$. In replicate groups twelve rats were killed $7 \mathrm{~d}$ after dosing with the tracer, six were killed $22 \mathrm{~d}$ after dosing and the remaining six, $28 \mathrm{~d}$ after dosing. The kidneys and liver were sampled for histological examination and solution in NCS (Amersham/Searle Corp). The urine was sampled for solution in PCS (Amersham/Searl Corp). The faeces were freeze-dried, ground and sampled for combustion in a Packard 305 Sample Oxidizer. The radioactivity of hepatic, faecal and urinary samples was measured in duplicate in a Beckmann scintillation counter.

\section{Expl 4}

The design of this experiment was similar to that of Expt 3 apart from the inclusion of mixed aflatoxins at a constant rate of $1.4 \mathrm{mg}$ aflatoxin $\mathrm{B}_{1} / \mathrm{kg}$ diet throughout the experiment. The ingredient composition of the diets compared was that of diets $\mathrm{F}$ and $\mathrm{J}$ previously used in Expts 2 and 3 respectively. The polysaccharide content consisted of $363 \mathrm{~g}$ maize starch $/ \mathrm{kg}$ in diet $\mathrm{J}$, and $63 \mathrm{~g}$ maize starch plus $300 \mathrm{~g}$ wheat offal $/ \mathrm{kg}$ in diet $\mathrm{F}$.

After $28 \mathrm{~d}$ the biotin content of both diets was raised to $880 \mu \mathrm{g} / \mathrm{kg}$ at which level it was maintained for the remainder of the experiment, although no symptoms of biotin deficiency had been observed and no effect on subsequent performance was recorded.

One day's food allowance was omitted $186 \mathrm{~d}$ from the initiation of the experiment and $4 \mathrm{~g}$ food containing $0.8 \mu \mathrm{Ci}{ }^{14} \mathrm{C}$-labelled aflatoxin $\mathrm{B}_{1}$ (Moravek Biochemicals, City of Industry, California 91745, USA) were given to each rat on the following day. During the following $7 \mathrm{~d}$ the food allowance was raised to $9 \mathrm{~g} / \mathrm{rat}$ daily. As in the previous experiment tail cups had been fitted $24 \mathrm{~h}$ before administering the tracer but left in place for $8 \mathrm{~d}$. The faeces voided were divided into three consecutive periods, of lengths 48,48 and $72 \mathrm{~h}$ respectively and the urine was divided into two consecutive periods of lengths 48 and $120 \mathrm{~h}$ respectively. Six replicates were killed $7 \mathrm{~d}$ after administering the ${ }^{14} \mathrm{C}$ dose, three replicates, $26 \mathrm{~d}$ after administration and three replicates $32 \mathrm{~d}$ after administration. The ${ }^{14} \mathrm{C}$ in the faeces, urine and livers was measured in the way described for Expt 3.

Both livers and kidneys were examined histologically in Expts 3 and 4. Notable pathological changes were observed only in the livers of Expt 4 and the results are given in Table 8.

\section{RESULTS}

\section{Expt 1}

Amongst the rats killed on days 93-95 aflatoxin was associated with an apparent, but non significant, enlargement of the liver (diet B v. diet A) which was less for those receiving lucerne (diet E v. diet B) and wheat bran (diet C v. diet B) (Table 1) however no hyperplastic nodules were observed in any of the eight liver sections prepared per rat killed at that time. A uniform distribution of periportal lipid accumulation in parenchymal cells stained with Oil Red-O was observed in control rats at 93-95 d. Rats receiving aflatoxin, especially in the absence of lucerne or bran showed irregular periportal distribution of fat; some cells appearing to be engorged.

At 109 weeks of age rats which had received the control diet (diet A) 93 weeks previously possessed larger carcasses than those which had received aflatoxin (diet B). The control rats at 109 weeks also had smaller livers than those which had received diet $\mathrm{B}(P<0.01)$, and smaller kidneys than those which had received diet $\mathrm{E}(P<0.05)$. 


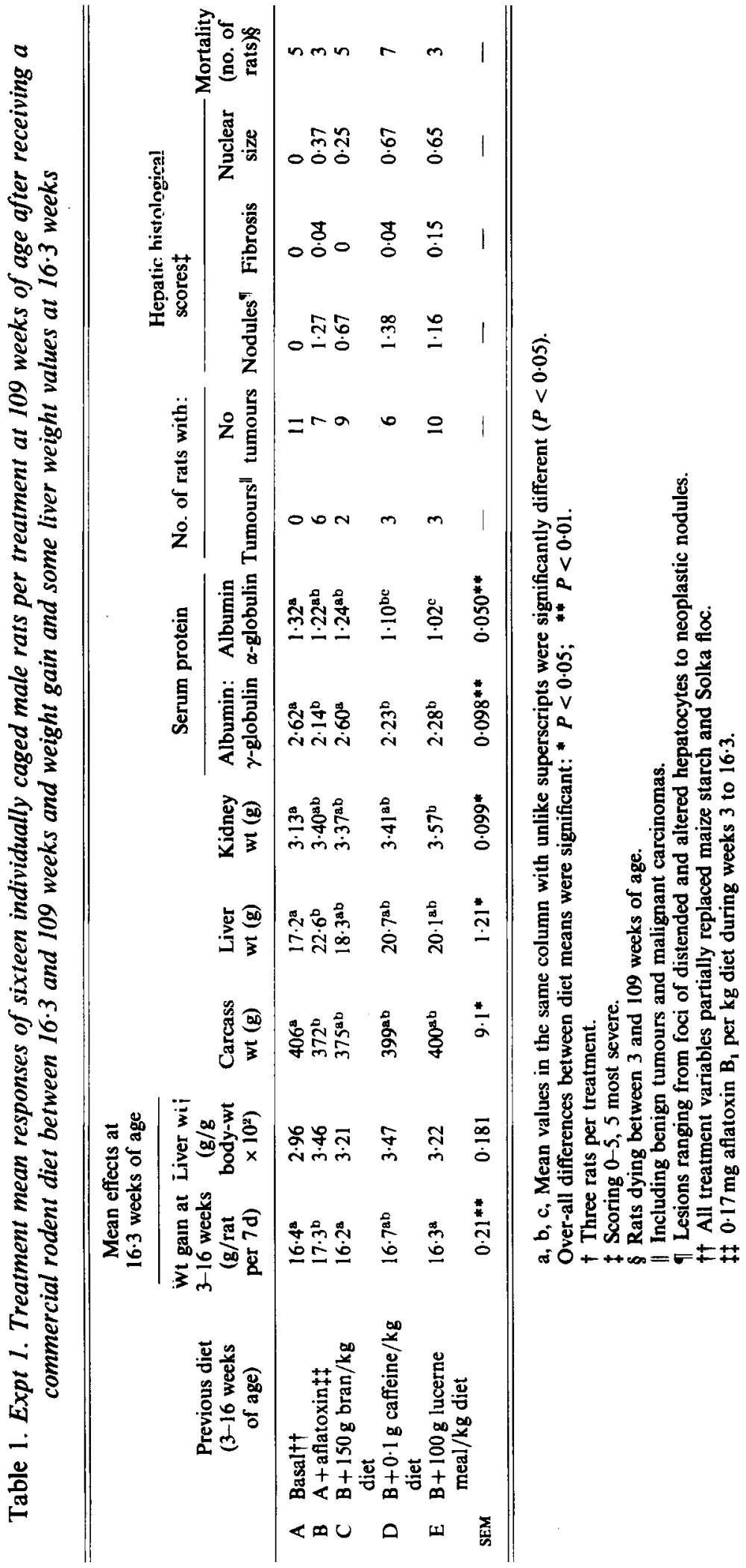




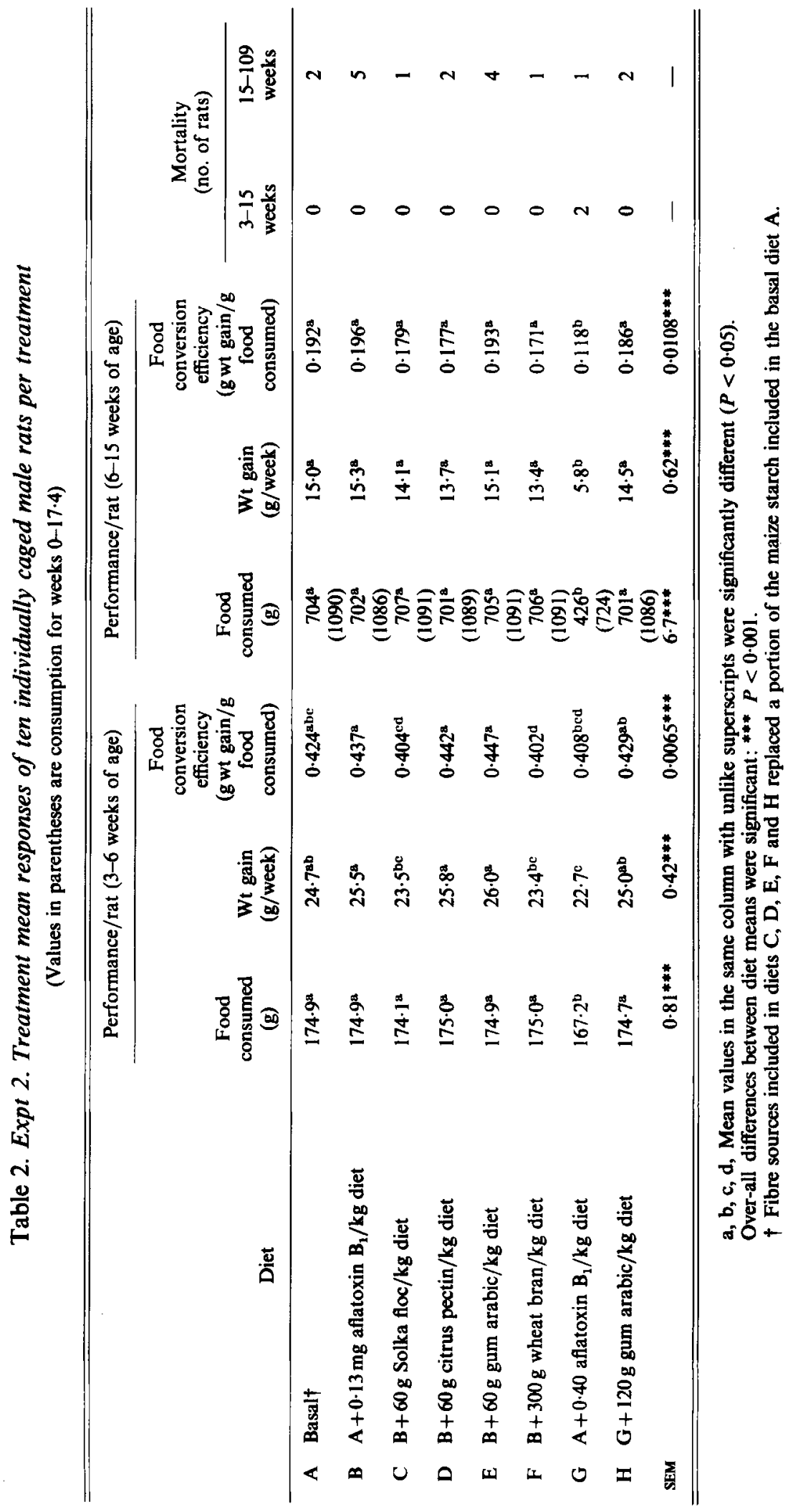


Serum albumin: $\gamma$-globulin was depressed in those rats which had received aflatoxin (diet B $v$. diet A) but where wheat offal had been given the value did not differ from that of the controls (diet $C \boldsymbol{v}$. diet A). Aflatoxin also depressed albumin: $\alpha$-globulin but the various supplements failed to redress the effect. Aflatoxin caused tumours in six of the sixteen rats where no supplements had been given but fewer where they had. The histopathological score was normal for the controls and the effect of aflatoxin was least pronounced where wheat offal had been given.

Caffeine has been shown to interact with DNA and inhibit chemical carcinogens (Yoskikura, 1974), but had no effect in this experiment.

\section{Expt 2}

During the first 3 weeks of the experiment the higher concentration of aflatoxin depressed body-weight gain and focd conversion efficiency ( $\mathrm{g}$ body-weight gain/g food consumed; FCE) in comparison with the lower (diet $G v$. diet B), but the depression in weight gain was overcome by adding gum arabic to the diet (diet $\mathrm{H} v$. $\operatorname{diet} \mathrm{G}$ ). As in the first experiment there was a tendency for the lower concentration of aflatoxin to stimulate weight gain (diet B $v$. $\operatorname{diet}$ A) (Table 2). Similar trends were observed during the remaining 9 weeks to 15 weeks of age when gum arabic, included with the higher level of aflatoxin, allowed a rate of gain similar to that observed for the basal diet (diet $\mathrm{H} v$. diet A). A comparison between two diets $L$ and $M$, identical respectively to $G$ and $H$ except for the omission of aflatoxin, yielded mean $( \pm \mathrm{SE}$ ) live-weight gains per week over an 8 week period of 9.29 and $9.02 \pm 0.13 \mathrm{~g} / \mathrm{rat}$ respectively and FCE values of 0.250 and $0.238 \pm 0.0036$ respectively. Hence the replacement of maize starch by gum arabic depressed FCE $(P<0.05)$ in the absence of aflatoxin and indicated a powerful interaction between carbohydrate source and aflatoxin dose. These two treatments were disccntinued after the initial feeding period.

Between 17.4 and 109 weeks of age when the commercial rodent diet was given a number of rats died, or were killecl, owing to ill health. At 109 weeks the stimulating effect of the low level of aflatoxin without supplement (diet B) had persisted, as measured by the difference in carcass weight from those receiving the diet containing the high concentration of aflatoxin (diet G) (Table 3).

Liver weight was elevated by the low level of toxin given without supplementation (diet B $v$. diet A). A similar but reverse trend was apparent for albumin: $\gamma$-globulin, but the ratio was depressed significantly only for diet $\mathrm{H}$. The rats which had received diet $\mathrm{H}$ also possessed enlarged livers. Small but significant $(P<0.05)$ differences occurred amongst the kidney weights. The kidneys of rats which had received the basal (diet A) were amongst the lower weights and those receiving aflatoxin without supplementation were amongst the heaviest (diet B).

Histological examination of liver sections (Table 3) showed an absence of hyperplastic nodules and tumours amongst control rats and these sections differed from all others in nodule scores. A comparison of diets A-F indicated that diet B had apparently caused the greatest over-all pathological change. Diets $B$ and $C$ led to the highest hyperplastic nodule scores. Diets E and F (gum arabic and wheat bran) tended to produce the least pathological changes.

\section{Expt 3}

The excretion of ${ }^{14} \mathrm{C}$ in the faeces during the first $72 \mathrm{~h}$ was five times that voided during the remaining $96 \mathrm{~h}$ (Table 4 ), and urinary ${ }^{14} \mathrm{C}$ excreted during the first $48 \mathrm{~h}$ was three times as great as that excreted cluring the remaining $120 \mathrm{~h}$ (Table 5). There was no significant difference amongst treatments in the total ${ }^{14} \mathrm{C}$ activity found in faeces or urine.

At $7 \mathrm{~d}$ after dosing with ${ }^{14} \mathrm{C}$ the livers contained more activity than at 22 or $28 \mathrm{~d}$ after 


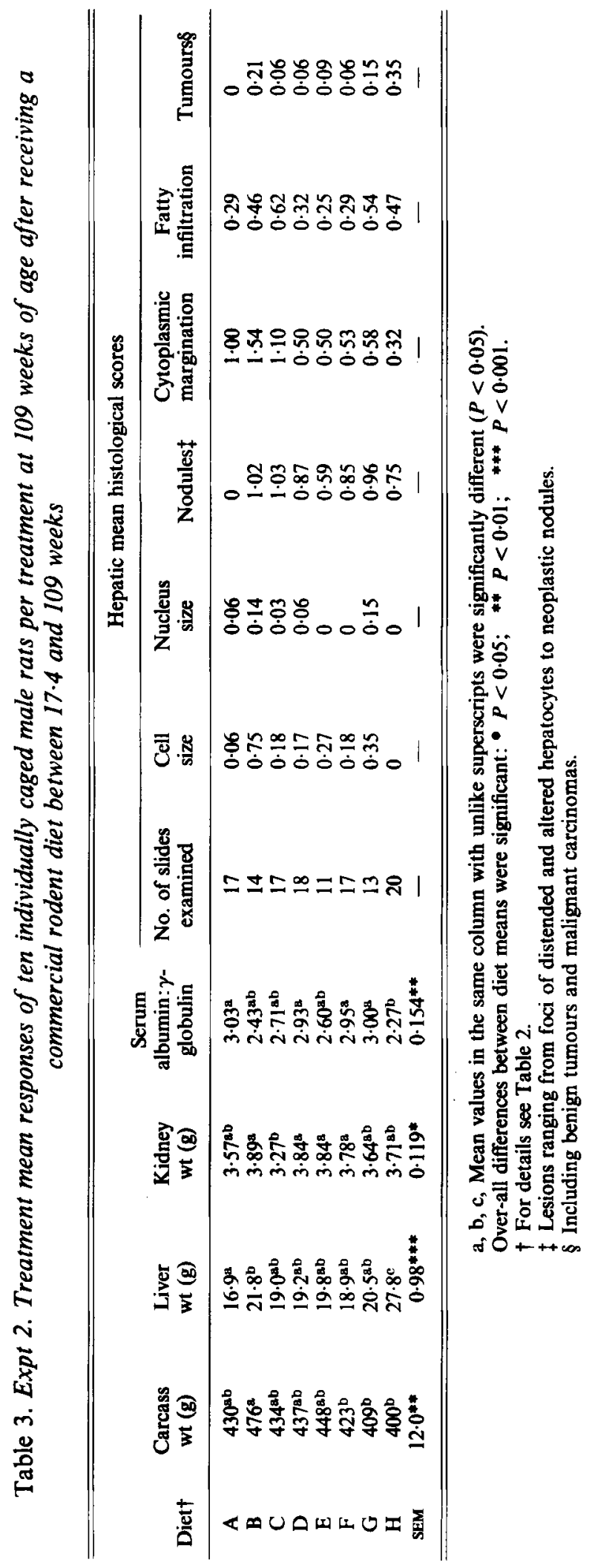


Table 4. Expts 3 and 4. Mean total faecal ${ }^{14} \mathrm{C}$ radioactivity (disintegrations $/ \mathrm{min} \times 10^{-5}$ ) of twelve individually caged male rats per treatment per experiment

\begin{tabular}{|c|c|c|c|c|c|c|}
\hline \multirow[b]{2}{*}{ Expt no. } & \multirow[b]{2}{*}{ Diet } & \multirow{2}{*}{$\begin{array}{l}\text { Carbohydiate } \\
\text { source }\end{array}$} & \multicolumn{3}{|c|}{ Time after meal given (h) } & \\
\hline & & & $0-72$ & $72-168$ & $0-168$ & \\
\hline 3 & $\underset{\text { SEM }}{\mathbf{J}}$ & $\begin{array}{l}\text { Starch } \\
\text { Gum arabic } \dagger\end{array}$ & $\begin{array}{c}11.7 \\
11.5 \\
0.56\end{array}$ & $\begin{array}{l}1.9 \\
2.6 \\
0.30\end{array}$ & $\begin{array}{c}13.6 \\
14.1 \\
0.44\end{array}$ & \\
\hline 4 & $\begin{array}{c}\mathbf{J} \\
\mathbf{F} \\
\text { SEM }\end{array}$ & $\begin{array}{l}\text { Starch } \\
\text { Wheat offal }\end{array}$ & $\begin{array}{c}0-48 \\
5.6 \\
13.6 \\
0.67^{* * * *}\end{array}$ & $\begin{array}{l}48-96 \\
4 \cdot 4 \\
1 \cdot 1 \\
0 \cdot 46^{* * *}\end{array}$ & $\begin{array}{l}96-168 \\
0 \cdot 83 \\
0 \cdot 19 \\
0.088 * * *\end{array}$ & $\begin{array}{l}0-168 \\
11 \cdot 0 \\
15 \cdot 0 \\
0.46^{* * *}\end{array}$ \\
\hline
\end{tabular}

$* * P<0.001$

† One rat was a significant outlier in all periods and has been omitted.

Table 5. Expts 3 and 4. Mean total urinary ${ }^{14} \mathrm{C}$ radioactivity (disintegrations $/ \mathrm{min} \times 10^{-5}$ ) of twelve individually caged male rats per treatment per experiment

\begin{tabular}{|c|c|c|c|c|c|}
\hline \multirow[b]{2}{*}{ Expt no. } & \multirow[b]{2}{*}{ Diet } & \multirow{2}{*}{$\begin{array}{l}\text { Carbohydrate } \\
\text { source }\end{array}$} & \multicolumn{3}{|c|}{ Time after meal given (h) } \\
\hline & & & $0-48$ & $48-168$ & $0-168$ \\
\hline 3 & $\underset{\text { SEM }}{\mathbf{J}}$ & $\begin{array}{l}\text { Starch } \\
\text { Gum arabic } \dagger\end{array}$ & $\begin{array}{l}3.06 \\
2.96 \\
0 \cdot 127\end{array}$ & $\begin{array}{l}0.97 \\
1.03 \\
0.055\end{array}$ & $\begin{array}{l}4 \cdot 03 \\
3.99 \\
0 \cdot 104\end{array}$ \\
\hline 4 & $\begin{array}{c}\mathbf{J} \\
\mathbf{F} \\
\mathbf{S E M}\end{array}$ & $\begin{array}{l}\text { Starch } \\
\text { Wheat offal }\end{array}$ & $\begin{array}{l}4 \cdot 11 \\
3.38 \\
0.091^{* * * *}\end{array}$ & $\begin{array}{l}0.63 \\
0.36 \\
0.030^{* * *}\end{array}$ & $\begin{array}{l}4.74 \\
3.74 \\
0.081^{\text {*n* }}\end{array}$ \\
\hline
\end{tabular}

*** $P<0.001$

$\dagger$ One rat was a significant outlier in all periods and has been omitted.

Table 6. Expts 3 and 4. Effect of period (d) after dosing with ${ }^{14} C$-labelled aflatoxin $B_{1}$ on mean radioactivity of liver of twelve individually caged male rats per treatment per experiment

\begin{tabular}{|c|c|c|c|c|c|c|}
\hline \multirow[t]{2}{*}{ Expt no.... } & \multicolumn{3}{|c|}{3} & \multicolumn{3}{|c|}{4} \\
\hline & $\begin{array}{l}\text { Period } \\
\text { after } \\
\text { dosing } \\
\text { (d) }\end{array}$ & $\begin{array}{l}\text { Jose of non- } \\
\text { radioactive } \\
\text { aflatoxin } \\
\text { (mg/rat) }\end{array}$ & $\begin{array}{c}{ }^{14} \mathrm{C} \text { (dis- } \\
\text { integrations } \\
/ \text { min per } \\
\text { liver } \times 10^{-4} \text { ) }\end{array}$ & $\begin{array}{l}\text { Period } \\
\text { after } \\
\text { dosing } \\
\text { (d) }\end{array}$ & $\begin{array}{l}\text { Dose of non- } \\
\text { radioactive } \\
\text { aflatoxin } \\
\text { (mg/rat) }\end{array}$ & $\begin{array}{l}{ }^{14} \mathrm{C} \text { (dis- } \\
\text { integrations } \\
/ \mathrm{min} \text { per } \\
\text { liver } \times 10^{-4} \text { ) }\end{array}$ \\
\hline & $\begin{array}{c}7 \\
22 \\
28 \\
\text { SEM }\end{array}$ & $\begin{array}{l}0.589 \\
0.935 \\
1.063\end{array}$ & $\begin{array}{l}3.62 \\
1.49 \\
1.73 \\
+0.190^{* * *}\end{array}$ & $\begin{array}{r}7 \\
26 \\
32\end{array}$ & $\begin{array}{l}0.993 \\
1 \cdot 131 \\
1 \cdot 219\end{array}$ & $\begin{array}{c}1.68 \\
1.51 \\
0.92 \\
\ddagger 0.121 * *\end{array}$ \\
\hline
\end{tabular}

** $P<0.01 ; * * * P<0.001$.

+22 and $28 \mathrm{~d}$; SEM for $7 \mathrm{~d}=0 \cdot 190 / \sqrt{ } 2$.

$\ddagger 26$ and $32 \mathrm{~d}$; SEM for $7 \mathrm{~d}=0 \cdot 121 / \sqrt{ } 2$. 
Table 7. Expts 3 and 4. Mean liver weight and ${ }^{14} \mathrm{C}$ radioactivity of twelve individually caged male rats per treatment per experiment

\begin{tabular}{|c|c|c|c|c|}
\hline $\begin{array}{c}\text { Expt } \\
\text { no. }\end{array}$ & Diet & $\begin{array}{c}\text { Carbohydrate } \\
\text { source }\end{array}$ & $\begin{array}{l}\text { Liver wt } \\
(\mathrm{g} / \mathrm{g} \text { carcass } \\
\left.\mathrm{wt} \times 10^{2}\right)\end{array}$ & $\begin{array}{c}{ }^{14} \mathrm{C} \\
\text { (disintegrations/ } \\
\text { min per liver } \\
\times 10^{-4} \text { ) }\end{array}$ \\
\hline 3 & $\underset{\text { SEM }}{\mathbf{J}}$ & $\begin{array}{l}\text { Starch } \\
\text { Gum arabic }\end{array}$ & $\begin{array}{l}3.78 \\
3.60 \\
0.036^{* *}\end{array}$ & $\begin{array}{l}2 \cdot 64 \\
2 \cdot 59 \\
0 \cdot 134\end{array}$ \\
\hline 4 & $\begin{array}{c}\mathbf{J} \\
\mathbf{F} \\
\text { SEM }\end{array}$ & $\begin{array}{l}\text { Starch } \\
\text { Wheat offal }\end{array}$ & $\begin{array}{l}4.26 \\
3.66 \\
0 \cdot 120^{* *}\end{array}$ & $\begin{array}{l}1.62 \\
1.28 \\
0.086^{*}\end{array}$ \\
\hline
\end{tabular}

$* P<0.05, \quad * * P<0.01$.

dosing $(P<0.001)$ (Table 6). No decline in liver ${ }^{14} \mathrm{C}$ was apparent between the 22 nd and 28 th day. The total activity of the livers in rats given diet $\mathrm{K}$ was not significantly less than that of the livers of rats given diet $\mathrm{J}$, but liver weight as a fraction of carcass weight was less for diet $\mathrm{K}(P<0.01)$ (Table 7$)$.

\section{Expt 4}

The faeces voided during the first $7 \mathrm{~d}$ after administration of the ${ }^{14} \mathrm{C}$-labelled aflatoxin were divided into three consecutive periods, and the urine excreted was divided into two consecutive periods. The radioactivity of faeces of rats given diet $F$ was much greater than that of the faeces of rats given diet $\mathrm{J}$ during the first $48 \mathrm{~h}(P<0.01)$, but was less thereafter $(P<0.001)$ (Table 4). The majority of the ${ }^{14} \mathrm{C}$ was, however, voided during the first $48 \mathrm{~h}$ so that over all more was voided by the rats given diet $\mathrm{F}(P<0.01)$. The urinary ${ }^{14} \mathrm{C}$ was greater in each period for rats receiving diet $\mathrm{J}(P<0.001)$ (Table 5$)$, and again the majority of the ${ }^{14} \mathrm{C}$ was collected during the first $48 \mathrm{~h}$. However the total ${ }^{14} \mathrm{C}$ recovered in urine + faeces during $168 \mathrm{~h}$ was greater amongst rats on diet $\mathrm{F}(P<0.05)$. The ${ }^{14} \mathrm{C}$ retained in the livers at death was found to be greater amongst the rats given diet $\mathrm{J}(P<0.05$; Table 7 ), and there was a gradual decline in this activity over a period of $25 \mathrm{~d}$ during which the various groups were killed, commencing $7 \mathrm{~d}$ after dosing $(P<0.01$; Table 6$)$.

The amount recovered from the liver represented the proportion 0.239 of that recovered from the excreta in rats which had received diet $\mathrm{J}$, whereas the equivalent proportion for Diet $F$ was $0 \cdot 156$. The livers of rats given diet $J$ were larger as a fraction of carcass weight than the livers of rats given diet $F(P<0.01)$ (Table 7).

Histological examination of the livers showed a slightly greater incidence of fat accumulation amongst rats which had received diet $\mathrm{J}(P<0.001)$, otherwise the differences apparent were not significant (Table 8).

\section{DISCUSSION}

All concentrations of aflatoxin tested caused liver enlargement and a depression in serum albumin: $\gamma$ globulin. The latter value was shown to result from an elevation in serum $\gamma$-globulin without a change in the albumin, in accord with an elevated total serum protein which has been shown to occur after liver tumour induction (Newberne et al. 1966).

Wheat offal partially suppressed the short term (3-16 weeks of age) and long-term (up to 2 years of age) effects of dietary aflatoxin on liver size and structure. Of the nutrients 
Table 8. Expt 4. Mean histological scoring of liver sections $\dagger$ of twelve individually caged male rats per treatment

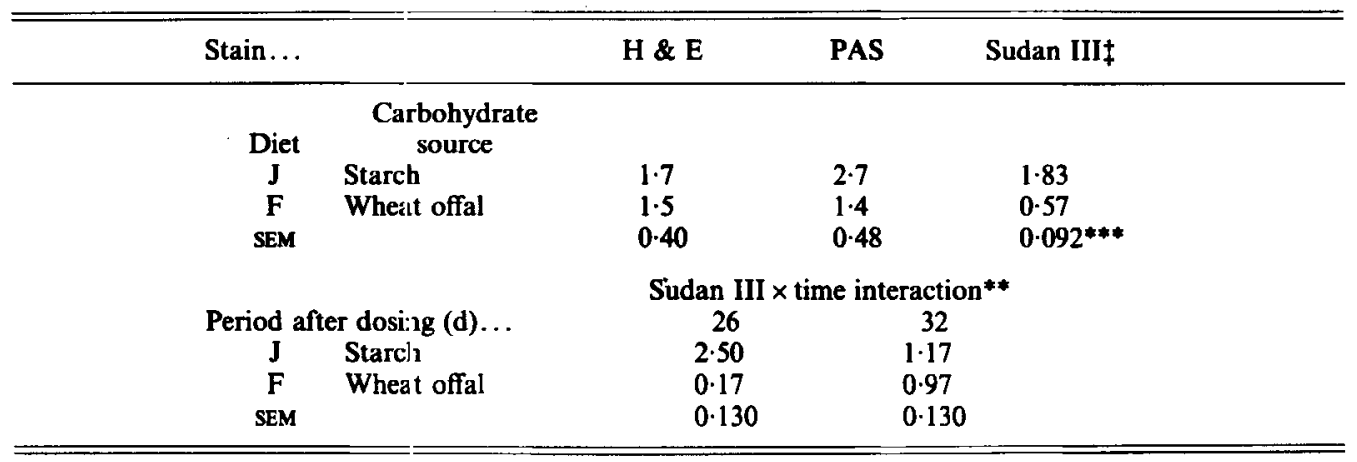

** $P<0.01$, **** $P<0.001$.

$\dagger 0$, normal; 5 , grossly abnormal.

$\ddagger$ Scored for presence of engorged cells.

contained in bran the proteins and water-soluble vitamins might in particular have been considered significant sources in the context of these experiments. Both protein (Madhavan \& Gopalan, 1965) and riboflavin (Newberne et al. 1974) have been shown to affect aflatoxicosis. However, the diets were rich in high-quality protein, although neither the quantity of dietary protein nor that of the B-vitamins was controlled between treatments. Possibly certain nutrients in excess of minimum requirements may afford some protection by stimulating metabolism.

Suppression of aflatoxin metabolism through a deficiency of dietary lipotropes protects against acute toxicity but enhances the carcinogenicity of aflatoxin given by injection (Rogers \& Newberne, 1971 ; Butler \& Neal, 1973). A dietary deficiency of either lipotropes or protein decreases the ac ivity of microsomal demethylating enzymes and hydroxylases (Madhaven \& Gopalan, 1965; McLean \& McLean, 1967; Rogers \& Newberne, 1971) suggesting that intermediary metabolites are responsible for the acute toxic effects. The 2-hydroxy derivatives are considered to be of particular toxic significance in fast metabolizing species (Patterson \& Allcroft, 1970). A retardation of these reactions, during protein deficiency, with an intracellular accumulation of the untransformed toxins, which react with DNA (Wogan \& Pong, 1970), accentuates the carcinogenic properties of aflatoxin (Newberne et al. 1966; Rogers and Newberne, 1971). A stimulation of the activity of these enzymes by means of drugs (McLean \& McLean, 1969; McLean \& Marshall, 1971) or dietary protein (Madhavarı \& Gopalan, 1965) increases the excretion of the 4-hydroxy derivative (aflatoxin $\mathbf{M}_{1}$ ), the demethylated phenolic derivative (aflatoxin $\mathbf{P}_{1}$ ), and probably other metabolites partially suppressing the carcinogenic properties (Patterson, 1973). A starch-rich diet elicits a greater urinary aflatoxin $\mathbf{M}_{1}$ excretion than a sucrose-rich diet in rats (Wise et al. 1978). In this experiment urinary losses seemed to reflect the amount of ${ }^{14} \mathrm{C}$ absorbed and thin-layer chromatography of urinary extracts followed by autoradiography showed no differences amongst treatments in the distribution of the activity; the majority having an $R_{f}$ equel to that of aflatoxin $\mathrm{M}_{1}$. Dickerson et al. (1971) reported that the replacement of dietary starch by sucrose depresses cytochrome P-450, and cytochrome $P-450$ reductase. Although all diets contained starch, as maize starch, and in the instance of wheat offal in particular, as a component of the test ingredient, it is possible that differences amongst diets in starch content may have contributed to the effects observed, 
the greater amount of starch stimulating hepatic formation and urinary excretion of aflatoxin $M_{1}$. Nevertheless the rats receiving diets containing the greater amount of starch still retained more ${ }^{14} \mathrm{C}$ in their livers.

As the metabolites which cause acute and chronic effects may differ (Patterson, 1973) and as wheat offal appears to ameliorate all toxic effects the observations are consistent with an influence of the offal on the initial absorption of aflatoxin $B_{1}$ from the intestines.

In both Expts 3 and 4 the mean ( $\pm \mathrm{SE}$ ) rate of faecal dry matter (DM) excretion $(\mathrm{g} / \mathrm{h})$ was much greater for the diets containing the structural carbohydrates, 0.0159 and $0.0236 \pm 0.00065(P<0.001) \mathrm{g} /$ rat per $\mathrm{h}$ for diets $\mathrm{J}$ and $\mathrm{K}$ respectively, and 0.0127 and $0.0258 \pm 0.00054(P<0.001) \mathrm{g} /$ rat per $\mathrm{h}$ for diets $\mathrm{J}$ and $\mathrm{F}$ respectively. Thus gum arabic increased the rate by $48 \%$ whereas wheat offal increased it by $103 \%$. Despite an increase in the faecal DM recovered from gum arabic-fed rats which was nearly half the increase in the wheat offal-fed rats, the gum arabic had no significant effect on ${ }^{14} \mathrm{C}$ distribution. Wheat offal accelerated the rate of passage of ${ }^{14} \mathrm{C}$ and increased the total amount of ${ }^{14} \mathrm{C}$ recovered from the faeces within $168 \mathrm{~h}$. Faecal bulk itself may therefore not have been a determinant of faecal ${ }^{14} \mathrm{C}$.

Less ${ }^{14} \mathrm{C}$ was retained in the liver and excreted in the urine by the offal-fed rats and the simplest explanation of the observations is that the intestinal absorption of the toxin was decreased as a result of an accelerated rate of passage, or the adsorption of the toxin was dietary residues or both. This explanation does not, however, exclude the possibility that metabolism by, and removal from, the liver of aflatoxin $M_{1}$ in particular was affected by the starch, or other factors, in the diet. These and other possibilities are being explored.

The authors wish to aknowledge A. J. Newman (Lee Newman Research Associates) Barnstaple, Devon for an independent assessment of half the histological sections cut. The authors are also grateful to Dr N. W. R. Daniels, Dalgety Spillers Ltd for helpful criticism of the text and to S. Foster, A. Lyons and P. Saunders for technical assistance.

\section{REFERENCES}

Alfin-Slater, R. B., Aftergood, L. \& Wells, P. (1975). J. Am. Oil Chem. Soc. 52, 266.

Butler, W. H. \& Neal, G. E. (1973). Cancer Res, 33, 2878.

Dickerson, J. W. T., Basu, T. K. \& Parke, D. V. (1971). Proc. Nutr. Soc. 30, 27A.

Frape, D. L., Wayman, B. J. \& Tuck, M. G. (1979). J. Agric. Sci., Camb. 93, 133.

Frape, D. L., Wayman, B. J. \& Wilkinson, J. (1981 a). Nutr. Rep. Int. 23(1), 163.

Frape, D. L., Wayman, B. J. \& Wilkinson, J. (1981 b). Nutr. Rep. Int. 23(1), 171.

Frape, D. L., Wilkinson, J. \& Chubb, L. G. (1970). Lab. Anim. 4, 67.

McLean, A. E. M. \& McLean, E. K. (1967). Proc. Nutr. Soc. 26, xiii.

McLean, A. E. M. \& McLean, E. K. (1969). Br. med. Bull. 25, 278.

McLean, A. E. M. \& Marshall, A. (1971). Br. J. exp. Path 52, 322.

Madhavan, T. V. \& Goplan, C. (1965). Archs. Path. 80, 123.

Ness, A. T., Dickerson, H. C. \& Pastewka, J. V. (1965). Clinica chimica Acta, 12, 532.

Newberne, P. M., Chan, W-C. M. \& Rogers, A. E. (1974). Toxic. appl. Pharmac. 28, 200.

Newberne, P. M., Harrington, D. H. \& Wogan, G. N. (1966), Lab. Invest. 15, 962.

Owen, D. E., Munday, K. A., Taylor, T. G. \& Turner, M. R. (1975). Proc. Nutr. Soc. 34, 16A.

Patterson, D. S. P. (1973). Food \& Cosmet. Toxicol. 11, 287.

Patterson, D. S. P. \& Allcroft, R. (1970). Food \& Cosmet. Toxicol. 8, 43.

Ranhotra, G. S., Loewe, R. J. \& Puyat, L. V. (1977). J. Fd. Sci. 42, 1587.

Riottot, M., Sacquet, E., Mejean, C. \& Leprince, C. (1975). Nutr. Rep. Int. 12, 1.

Rogers, A. E. \& Newberne, P. M. (1971). Nature, Lond. 229, 62.

Wicks, A. C. B., Yeates, J. \& Heaton, K. W. (1978). Scand. J. Gastroenterol. 13, 289.

Wise, A., Suzangar, M., Messripour, M. \& Mohammade, J. (1978). Br. J. Nutr. 40, 397.

Wogan, G. N., Paglialunga, S. \& Newberne, P. M. (1974). Food \& Cosmet. Toxicol. 12, 681.

Wogan, G. N. \& Pong, R. S. (1970). Ann. N.Y. Acad. Sci. 174, 623.

Yacowitz, H., Fleischman, A. I. \& Kritchevsky, D. (1976). 2nd Jt. Mtg. Am. Inst. Nutr., Am. Soc. Clin. Nutr., Nutr. Soc. Can. 26, Abstr. 39.

Yoskikura, H. (1974). Nature, Lond. 252, 71. 